Leading article/Uvodnik

\title{
An Australian perspective on nurse education: a philosophical approach
}

\author{
Avstralski pogled na izobraževanje medicinskih sester: filozofski pristop
}

\author{
Daniel Nicholls
}

\section{Introduction}

When asked to write this Leading article I was at once presented with a conceptual difficulty: how to present the status of nurse education in Australia to a readership that had little or no exposure to the Australian setting on the one hand but on the other hand had a precise knowledge of nursing. This problem contained within itself an interesting question: can we say that nursing itself is an universal practice in that it is essentially the same wherever it occurs? Thus there are at least two outcomes to this paper: the first is an insight to nurse education in Australia, and the second some questions on the nature of nursing itself. My own academic education as a philosopher assisted me to see that these outcomes would be best addressed through a careful working through of the factors involved; both conceptual and experiential. To undertake this exercise I will utilise a combination of approaches, largely influenced by the work of Edmund Husserl (1970) and Ludwig Wittgenstein (1953). The phenomenological approach of Husserl requires me to suspend my judgment as I apprehend the objects of my experience - that is, nursing and its education are not unfamiliar to me; I have certain preconceived notions and attitudes derived from my experience which will colour any discussion or articulation of "facts". Wittgenstein's approach involves a discerning description which takes into account the vicissitudes of language.

Colouring is not a negative thing, as how would we know anything at all if there were not someone to tell us about it from a certain position or level of understanding? That is, any exegesis comes from someone whose consciousness is in the process of apprehending an object of consciousness. However, in phenomenology a position must be admitted, set aside and reassimilated. As an example of this fact we can see here that the very spelling of the word "colour" tells the reader quite a lot about the intellectual tradition of the writer. The Slovenian reader who knows very little about Australia but something more about the United Kingdom (UK) will immediately recognise that there may be a connection here that extends to practices other than spelling. They might surmise that the nursing tradition in Australia is closely connected to that of the UK - and in that they would be correct. Wittgenstein might say that it is not clear what the word "colour" refers to in any case, and here there are no colours to be had. With these perspectives in mind I will give some background context to the question at hand.

\section{Modern Australia}

Modern Australia emerged from a late eighteenth century background as an English colony and penal settlement, superimposed on a remarkable Aboriginal culture that stretches back for millennia. It thus has its roots in an amalgam of two very distinct cultural backgrounds. This double culture quickly became more complicated in the nineteenth and twentieth centuries through immigration from many other parts of the world. In the twenty-first century Australia continues to shift its cultural face with ever advancing migration. The issue of assimilation of cultural groups in Australia is ongoing and challenging (Ho, 2015). A dominant cultural group, perhaps that which gave Australia its common language and social practices, is no longer easy to recognise or define. For as migrant populations have assimilated into Australia, the "previous" Australia has itself assimilated into these populations. So for those visitors who expect to find a largely Anglo-Saxon-Celtic population, just because Australians speak English, will be as disappointed as when they visit Britain imagining to find the same thing. This is an important element in any discussion of nurse education in Australia as changing cultural concerns are a central issue.

Senior Lecturer Daniel Nicholls, RN, BA (Hons), PhD, Academic Course Advisor, International Students Onshore and Postgraduate Mental Health Courses; School of Nursing and Midwifery Western Sydney University, Locked Bag 1797 Penrith NSW 2751, Australia

Correspondence e-mail/Kontaktni e-naslov: d.nicholls@westernsydney.edu.au 
I have suggested elsewhere that much of what we do in nursing and health is influenced by imagination (Nicholls, 2014). With regard to mental health I termed this phenomenon "the mental health imaginary". The "imaginary" should not be capitalised as that might give it an undue status as a universal concept rather than a way of approaching our thinking and reasoning (Le Doeuff, 1989). It concerns how we imagine ourselves in our everyday lives and how we imagine the conditions that we treat - and what we say and write about these. For the purposes of this paper I will apply the notion of the imaginary to how we might imagine nurse education in Australia in 2015.

\section{The educational transition}

Nurse education in Australia began as "training". That is, following the lead of Florence Nightingale Australian hospitals endeavoured to provide the best hygiene standards. Nurses were trained in tasks. This approach continued for much of the twentieth century until a radical shift occurred in both the nature of nursing and the way it was taught. The move to university education happened progressively with nurses first moving to a system of nursing diplomas, either directly or as a conversion from their hospital certificates. This is an inter-national phenomenon (Forber, et al., 2015). In Australia the situation created some problems in the workplace with some employers questioning whether someone held a diploma or a postgraduate diploma: there were salary implications. Even now there are nurses who hold many diplomas and certificates but do not hold a Bachelor's degree. There are conversion courses to degrees and some people have taken several steps to get there. In a sense then some nurses have been disadvantaged over this long period of transition to university education. To address this anomaly there is provision to grant recognition of prior learning for post basic nursing experience. There are financial incentives for nurses to gain postgraduate qualifications but these incentives stop at the level of a Master's degree. There is no direct financial incentive to progress to a higher degree by research. There are however other incentives. Among these is employment at a university.

Employment requirements for universities have also changed over time. At one time it was sufficient to hold a Bachelor's degree to teach in a university and that is theoretically still the case as academics are required to hold a minimum degree of the award in which they teach. But to obtain tenure it is becoming more and more necessary that applicants hold a $\mathrm{PhD}$ or are working towards a $\mathrm{PhD}$. One of the rationales behind this movement is that universities are becoming more research focussed. With this in mind universities have granted study time for academics who are $\mathrm{PhD}$ candidates. Of course there are still those who hold a Bachelor's or Master's degree and some of these academics are also researchers. A complication however is that some highly experienced nurses are unable to move to university employment, except perhaps as casual teachers. This can be seen as highly insulting or humiliating for nurses with substantial professional standing. Thus they may choose to remain in the clinical arena where they can influence nurse education in other ways.

This duality of perception in terms of standing does have impacts on student nurses and the ways that they perceive themselves and their education. At university they are required to perform academically, as well as being evaluated on their clinical competence. Within clinical practice, on the other hand, they are evaluated on their clinical competence by highly qualified nurses who may not be able to obtain an academic appointment. It is evident that there is a disparity here. Interestingly, this divide mirrors to some extent the situation of hospital training where the nurse education centre staff held a particular status vis-à-vis ward staff. Even then, I recall, there were complaints from ward staff about "what we were learning" at the education centre. The converse was also the case.

\section{Imagining the future of nurse education}

In these brief words I am attempting to highlight a couple of issues as I see them: one is the disparity in just who is considered entitled to teach in a particular setting; another is the changing cultural face of Australia, a cultural face which must surely impact the way that nurses are both taught and viewed. In my own university there have been significant inroads made into respecting the needs of students from all cultures (both international and local students). There are intensive literacy resources employed, for example - and not just available to those for whom English is a second or third language. Importantly it was recognised that literacy is a crucial aspect of the professional lives of all registered nurses: the increase in students for whom English is not the first language meant that universities started to embrace their responsibility in this regard.

It is clear that the face of nursing will not remain fixed. Nurses are educated very differently today from the 1970s, for example. At that time one could expect that the majority of nurses "looked " as though they may be of an Anglo(ish) origin, espousing all the educational and moral attributes that we might imagine belong to this group. There were strict codes about how to address each other, doctors and others. Some of my own educators on the wards were indeed from other cultures, but as I recall these were from countries where English was a national language; e.g., The Philippines or Canada. The English language and what was considered the English way of life were the dominant features of any hospital setting. In some 
wards, and in higher administration, nurses made tea for the doctors, sometimes with silver services. This did seem to me an anachronism in a country which purported to be free of a class system.

Of course, in a country which welcomes (or not) many from other cultures, there are bound to be differences in self-perception. It can easily be imagined that some immigrant nurses would still honour perceived status in the way I have just described. There may also be attitudes about the status of women and perceptions and beliefs about other gender dynamics; for example, whether male nurses should be permitted to perform procedures on women patients. These dynamics were addressed long ago in Australia, but it is no stretch of the imagination to comprehend how they may still be acute dynamics in some cultures. Thus there is a need to acknowledge the need for a constant return to questions which were once seemingly resolved. This is not to suggest that the host country is free from its own biases and attitudes. There is a need for all nurses to consider the beliefs and assumptions they carry into the workplace.

\section{Conclusion}

I have provided a brief glimpse into how I see nurse education in Australia in terms of the past, the present, and a possible future. In fact each of these timeframes is only possible, as I have described them from my own perspective in the context of some contextual facts; even these as I saw them. What did become apparent to me in writing the paper were the vast possible differences in perception vis-à-vis nursing and its education. Even in Australia, a seemingly homogenous society, there have been historical differences depending on local perceptions and requirements. I wonder whether the national nursing register, established in 2010, really does overcome these local differences, and indeed, whether it should. For example, a nurse in a remote region of Australia providing services to a particular, small group of people, may have very little in common with a nurse working at a teaching hospital in a large city. These differences may impact on many aspects of nursing and its education: interdisciplinary interactions; family and social interventions; cultural expectations - the list is not exhaustive. I also wonder whether I can ever really know how nursing is perceived in a place like Slovenia, where thousands of years of history separate me from those who may say they have the same profession as me. I sense that we may have a lot in common, for example a focus on the holistic needs of a patient, but I also sense that we may have many differences in perception related to our own personal, cultural, linguistic and professional histories. I don't believe we should try to elide these differences, but do think we need to learn from each other so that we can indeed try to meet the needs of our patients - who are all different, after all. This final thought raises its own question: if you are different from me should I expect you to agree?

\section{Slovenian translation/Prevod $v$ slovenščino}

\section{Uvod}

Ob povabilu, da prispevam ta uvodnik, sem se najprej soočil s konceptualnim problemom: kako predstaviti avstralski sistem izobraževanja medicinskih sester ciljni skupini bralcev, ki slabo ali morda sploh ne poznajo Avstralije, so pa strokovnjaki na področju zdravstvene nege. Ta problem zadeva zanimivo temeljno vprašanje - je zdravstvena nega univerzalna, enaka, kjerkoli se izvaja? Prispevek ima torej vsaj dva namena - predstaviti izobraževanje medicinskih sester $\mathrm{v}$ Avstraliji in samo naravo zdravstvene nege. Filozofska akademska izobrazba me je vodila najprej k podrobni preučitvi vseh ključnih konceptualnih kot tudi izkušenjskih dejavnikov. $\mathrm{V}$ ta namen sem združil več pristopov, ki v veliki meri temeljijo na delih Edmunda Husserla (1970) in Ludwiga Wittgensteina (1953). Husserlov fenomenološki pristop mi narekuje, da se pri obravnavi tematike oddaljim od ocene in vrednotenja lastnih izkušenj, saj mi področje zdravstvene nege ni nepoznano, prav tako pa tudi izobraževanje $\mathrm{v}$ tej stroki.Todamojelastneizkušnje, vnaprejšnja prepričanja in naravnanost bodo zanesljivo subjektivno obarvala mojo razpravo in členitev »dejstev«. Wittgensteinov pristop pa vključuje pretanjeno opisovanje, ki upošteva tudi pomenske preobrate $\mathrm{v}$ jezikovnem izražanju (Wittgenstein opozarja na dvoumnost in večpomenskost stavkov in poudarja uporabo preciznega jezika, ki omogoča objektivno zajemanje, opisovanje in preslikavanje resničnosti. Op. prev.).

Obarvanje (dejstev) samo po sebi ni slabo, saj omogoča spoznavanje različnih pogledov in različnih stopenj razumevanja sveta. To pomeni, da moja kritična razlaga ali interpretacija izhaja iz nekoga, čigar zavedanje je v procesu razumevanja objekta zavedanja. Toda v fenomenologiji moramo stališča sprejeti, jih postaviti na stran in nato ponovno povezati. Kot primer vzemimo moj zapis besede »colour « (v primerjavi z "color«, op. prev.), ki pove mnogo o intelektualnem ozadju avtorja. Slovenski bralci, ki slabo poznajo Avstralijo in vedo več o Združenem kraljestvu, bodo nemudoma opazili, da gre za povezave, ki presegajo pravopisna pravila. Predvidevajo lahko, da je tradicija zdravstvene nege $v$ Avstraliji tesno povezana s tradicijo v Združenem kraljestvu, in njihovo sklepanje bo pravilno. Wittgenstein bi morda zatrjeval, da ni jasno, na kaj se beseda »barva« pravzaprav nanaša, saj na tem mestu v nobenem pogledu ne obravnavamo barv. Ob upoštevanju teh vidikov bom predstavil ozadje preučevane tematike. 


\section{Avstralija današnjega časa}

Moderna Avstralija se je razvila iz angleške kolonije v poznem 18. stoletju, dežele, v kateri je Britanija naseljevala svoje kaznjence. Tu so živeli staroselci Aborigini s svojo izjemno večtisočletno kulturo in tradicijo. Moderna Avstralija ima torej svoje korenine $\mathrm{v}$ mešanici dveh popolnoma različnih kulturnih ozadij. $\mathrm{Ta}$ dvojnost kultur se je v 19. in 20. stoletju dodatno nadgradila $s$ priseljevanjem prebivalstva iz številnih drugih koncev sveta. Tudi v 21. stoletju Avstralija spreminja svojo kulturno podobo $\mathrm{z}$ vedno številnejšimi priseljenci. Asimilacija različnih kulturnih tradicij še traja in predstavlja poseben izziv (Ho, 2015). Danes se je težko opredeliti, katera kulturna skupina je v deželi prevladujoča - res še tista, ki je dala Avstraliji skupen jezik ter vzpostavila pravila in vrednote družbenega življenja? Priseljeni prebivalci so se asimilirali v "staro" Avstralijo, prav tako pa velja tudi obratno. Tisti, ki zaradi angleškega jezika $\mathrm{v}$ Avstraliji pričakujejo predvsem prebivalce pretežno anglosaškega in keltskega porekla, bodo morda presenečeni, enako presenečenje pa bi doživeli tudi v Veliki Britaniji, kjer je situacija podobna. To je pomemben dejavnik v vseh razpravah o izobraževanju na področju zdravstvene nege $\mathrm{v}$ Avstraliji, saj ima kulturno spreminjajoča se družba tu pomembno vlogo.

Kot sem zapisal že v drugih objavljenih prispevkih, imajo na prakso zdravstvene nege in zdravje prebivalstva vnaprejšnje predstave odločilen vpliv (Nicholls, 2014). V kontekstu mentalnega zdravja sem ta pojav poimenoval "mentalne predstave $o$ zdravju«. Besede "predstave « ne smemo pisati $z$ veliko začetnico, saj bi ji tako lahko pripisali neustrezen status univerzalnosti. Besedo je treba razumeti kot način pristopanja do našega razmišljanja, sklepanja in mišljenja (Le Doeuff, 1989). Beseda vključuje videnje samega sebe $\mathrm{v}$ vsakodnevnem življenju in način zaznave zdravstvenih problemov bolnikov v naši obravnavi. Prav tako pa je pomembno tudi, kako o njih govorimo ali pišemo. V prispevku bom uporabil ta pojem $\mathrm{v}$ predstavitvi videnja izobraževanja medicinskih sester v Avstraliji danes.

\section{Prehodi v izobraževanju}

Izobraževanje medicinskih sester $\mathrm{v}$ Avstraliji se je pričelo kot "usposabljanje» ob praktičnem delu. Po zgledu Florence Nightingale, so avstralske bolnišnice skušale zagotavljati najboljše higienske standarde. Medicinske sestre so se ob delu priučevale posameznih opravil in nalog. Ta pristop se je obdržal večji del 20. stoletja, dokler se ni zgodil pomemben in korenit preobrat tako v filozofiji kot tudi v praksi in izobraževanju medicinskih sester. Prehod do univerzitetnih programov je potekal postopoma, najprej s podeljevanjem diplom medicinskim ses- tram po zaključenem šolanju, pa tudi posredno $s$ priznavanjem bolnišničnih spričeval. Podobno pot je bilo v izobraževanju medicinskih sester potrebno prehoditi tudi $\mathrm{v}$ drugih deželah sveta (Forber, et al., 2015). To stanje je $\mathrm{v}$ avstralskih bolnišnicah določen čas predstavljalo problem glede priznavanja dodiplomske in podiplomske izobrazbe, predvsem zaradi višine nagrajevanja. Še danes je v Avstraliji precejšnje število medicinskih sester, ki imajo vrsto različnih diplom in spričeval, nimajo pa diplome ustreznega dodiplomskega študija (BSc in Nursing, op. prev.). Obstajajo sicer programi prekvalifikacije za pridobitev te diplome, vendar je pot do nje zapletena. Ugotavljamo lahko torej, da so bile nekatere medicinske sestre dolgo prikrajšane za možnost univerzitetnega študija v svoji stroki. V želji popraviti to stanje, se priznava izobrazba tudi na osnovi znanj, pridobljenih $\mathrm{v}$ delovni praksi. Podiplomsko izobraževanje $\mathrm{v}$ Avstraliji spodbujajo s finančno podporo, vendar le do magistrske stopnje. Prav tako ni neposredne finančne podpore za doseganje višje stopnje izobraževanja prek raziskovalnega dela, so pa druge možnosti, npr. zaposlitev na univerzi.

Zahtevani pogoji za delo na univerzi so se s časom prav tako spreminjali. V nekem obdobju je za učitelje zadostovala le dodiplomska izobrazba (BSc, op. prev.). Ponekod v teoriji še vedno velja, da mora imeti učitelj najmanj enako stopnjo izobrazbe, kot jo zagotavlja izobraževalna institucija, kjer poučuje. $\mathrm{Za}$ stalno profesuro pa se vedno pogosteje pojavlja zahteva po doktoratu ali vsaj vključenost $\mathrm{v}$ doktorski študij. Razlogom za zahteve po višji akademski stopnji botruje predvsem raziskovalna naravnanost univerz. Univerze spodbujajo doktorski študij tudi $\mathrm{z}$ omogočanjem študijskih dopustov. Seveda pa se v raziskovalno delo vključujejo tudi nekateri učitelji le $\mathrm{z}$ dodiplomsko stopnjo ali magistrsko izobrazbeno stopnjo. Še vedno je prisotna zadrega, da medicinske sestre $\mathrm{z}$ dolgoletnimi in bogatimi izkušnjami ne morejo sodelovati v izvedbi teh študijskih programov ali pa sodelujejo le občasno in $\mathrm{v}$ omejenem obsegu. Medicinske sestre s širokimi znanji, izkušnjami in strokovnim ugledom zaznavajo tak odnos kot izjemno ponižujoč in žaljiv, zato se odločajo ostati v klinični praksi, kjer lahko vplivajo na izobraževanje kadrov na drugačen način.

Ta dvojnost, ki zadeva družbeni ugled in položaj medicinskih sester, zagotovo vpliva na študente zdravstvene nege, na njihovo samozavedanje in pogled na njihovo izobraževanje. Na univerzi se od njih pričakujeta akademski študij in razvijanje kompetenc za delo s pacientom, $\mathrm{v}$ klinični praksi pa študentove klinične kompetence ocenjujejo visoko usposobljene medicinske sestre, ki same nimajo možnosti pridobiti mesta med univerzitetnimi učitelji. Seveda tu zaznavamo določena neskladja in razhajanja. Ta ločnica do neke mere zrcali situacijo v kliničnem usposabljanju v praksi, kjer so medicinske sestre inštruktorice imele poseben položaj v odnosu do oddelčnih medicinskih 
sester, ki niso sodelovale v delu s študenti. Spominjam se, da so se že v tistem času oddelčne medicinske sestre kritično odzivale na način izvajanja klinične prakse študentov, veljalo pa je tudi obratno.

\section{Vizija izobraževanja medicinskih sester}

V teh besedah sem želel na kratko povzeti nekaj glavnih problemov, ki jih na področju izobraževanja medicinskih sester zaznavam sam. Izpostavil sem razhajanje oz. neskladje $\mathrm{v}$ tem, kdo sme sodelovati $\mathrm{v}$ izobraževanju medicinskih sester $\mathrm{v}$ posameznih institucijah. Drugi omembe vreden vidik pa je kulturna podoba Avstralije, ki nedvomno vpliva na metode izobraževanja in vrednotenje dela medicinskih sester. $\mathrm{Na}$ univerzi, kjer poučujem, se $\mathrm{v}$ vedno večji meri upošteva potrebe študentov, ki prihajajo iz različnih kulturnih okolij v sami Avstraliji ali iz tujine. Med drugim daje univerza velik poudarek opismenjevanju, in to ne le pri študentih, katerih materni jezik ni angleščina. Funkcionalna pismenost je prepoznana kot ključni dejavnik za uspešno strokovno delo vseh diplomiranih medicinskih sester. Študentom, katerih prvi jezik ni angleščina, univerza nalaga odgovornost, da izpopolnijo svoja jezikovno pomanjkljiva znanja.

$\mathrm{Ni}$ potrebno posebej poudarjati, da se narava zdravstvene nege s časom spreminja. Izobraževanje medicinskih sester danes težko primerjamo $\mathrm{Z}$ izobraževanjem $\mathrm{v}$ sedemdesetih letih prejšnjega stoletja. V tistem času se je pričakovalo, da bodo vse medicinske sestre "videti«, kot da so anglosaških ali angleških korenin, $\mathrm{z}$ vsemi izobraževalnimi in moralnimi atributi, ki jih pripisujemo tej populaciji. Obstajala so stroga pravila glede naslavljanja drugih medicinskih sester, zdravnikov in drugih. Nekaj mojih učiteljev na oddelku je prihajalo iz drugih kulturnih okolij, kjer pa je bil, kot se spominjam, prvi jezik prav tako angleščina (npr. Filipini ali Kanada). Angleški jezik in angleški način življenja sta tedaj zaznamovala vsa bolnišnična okolja. $\mathrm{Na}$ oddelkih in tudi v višji upravi so medicinske sestre pripravljale čaj za zdravnike, včasih celo s srebrnim priborom. To se mi je tedaj zdelo v nasprotju s časom in navadami dežele, kjer naj bi veljala brezrazredna družba.

V državi, ki sprejema (ali pa tudi ne) priseljence $\mathrm{z}$ drugačno kulturno tradicijo, je zaznavanje samega sebe od posameznika do posameznika nujno različno. Prav lahko si predstavljamo, da se bodo nekatere priseljene medicinske sestre še vedno strinjale $\mathrm{Z}$ družbenimi pogoji, ki sem jih opisal. Verjetno je tudi, da bo še vedno prevladoval poseben odnos do žensk ter zaznave in prepričanja o dinamiki spolov. To zadeva vprašanja, kot je na primer, ali lahko diplomirani zdravstvenik ali zdravstveni tehnik opravlja zdravstveno nego in negovalne intervencije pri pacientkah. S temi vprašanji se Avstralija ukvarja že dolgo, vendar je prav neverjetno, kako prevladujoča je ta problematika $\mathrm{v}$ nekaterih kulturnih okoljih še danes. Tako se moramo vedno znova lotevati vprašanj, za katere smo menili, da so bila že davno rešena. To še ne pomeni, da država gostiteljica ni odpravila določenih pristranskosti, predsodkov in naravnanosti, zato bi morale prav vse medicinske sestre temeljito pretehtati svoja prepričanja, sklepanja in domneve, ki jih prinašajo v svoje delovno okolje.

\section{Zaključek}

$\mathrm{V}$ prispevku sem podal bežen vpogled $\mathrm{v}$ svoje videnje na preteklo, sedanje in predvideno prihodnje izobraževanje medicinskih sester $\mathrm{v}$ Avstraliji. Te predstavitve so le pogojno resnične, saj predstavljajo le moje vidike in temeljijo na osebnih izkušnjah $\mathrm{v}$ določenem kontekstu dogodkov. Ob pisanju prispevka mi je postalo še bolj jasno, da obstajajo velike individualne razlike $\mathrm{v}$ zaznavi zdravstvene nege in izobraževanja medicinskih sester. Tudi v Avstraliji, kjer je družba vsaj navidezno homogena, so bile v zgodovini pomembne razlike na tem področju, ki so jih pogojevale lokalne perspektive in potrebe. Sprašujem se, ali sistem zdravstvene nege na držav-nem nivoju zmore preseči razlike na lokalni ravni, in seveda, ali je to sploh potrebno. Poglejmo na primer položaj diplomirane medicinske sestre, ki oskrbuje specifično, omejeno skupino prebivalstva na odmaknjenem področju Avstralije. Ta medicinska sestra ima verjetno zelo malo skupnega $\mathrm{z}$ medi-cinskimi sestrami, ki delajo $\mathrm{v}$ univerzitetnih kliničnih centrih $\mathrm{v}$ večjih mestih. Te razlike $\mathrm{v}$ delovnem okolju lahko pomembno vplivajo na številne vidike zdravstvene nege $\mathrm{v}$ praksi in izobraževanju, predvsem kar zadeva interdisciplinarno sodelovanje, zdravstveno in socialno obravnavo družin, kulturna pričakovanja in še marsikaj. Sprašujem se tudi, ali bi kdaj koli mogel spoznati in oceniti vlogo zdravstvene nege v Sloveniji, saj me tisočletna zgodovina ločuje od tistih, ki tu opravljajo podoben poklic. Nedvomno delimo marsikatere skupne značilnosti, na primer $\mathrm{v}$ holistični obravnavi pacienta. $\mathrm{Na}$ drugi strani pa sem prepričan, da obstajajo med nami razlike, pred-vsem na področju osebne, kulturne, jezikovne in profesionalne preteklosti. Teh razlik ni smiselno odpravljati, lahko pa se učimo drug od drugega, da bomo znali bolje poskrbeti za naše bolnike, ki so vsak zase poseben in enkraten individuum. To zadnje poraja še zadnje vprašanje: če se vi razlikujete od mene, ali naj pričakujem, da se boste $\mathrm{z}$ menoj strinjali?

\section{Literature}

Forber, J., DiGiacomo, M., Davidson, P., Carter, B. \& Jackson, D., 2015. The context, influences and challenges for undergraduate nurse clinical education: continuing the dialogue. Nurse Education Today. pii: S0260-6917(15)00276-2.

http://dx.doi.org/10.1016/j.nedt.2015.07.006

PMid:26264968 
Ho, C., 2015. "People like us": School choice, multiculturalism and segregation in Sydney. Australian Review of Public Affairs. Available at:

http://www.australianreview.net/digest/2015/08/ho.html [22. 8. 2015].

Husserl, E., 1970. The crisis of European sciences and transcendental phenomenology. Evanston: Northwestern University Press.
Le Doeuff, M., 1989. The Philosophical Imaginary. Stanford: Stan-ford University Press.

Nicholls, D., 2014. The mental health imaginary vis-à-vis its nurses and Australian environs: an essay. Journal of Research in Nursing, 19 (7-8), pp. 580-589.

http://dx.doi.org/10.1177/1744987114557715

Wittgenstein, L., 1953. Philosophical Investigations. Oxford: Basil Blackwell.

Cite as/Citirajte kot:

Nicholls, D., 2015. An Australian perspective on nurse education: a philosophical approach. Obzornik zdravstvene nege, 49(3), pp. 176-181. http://dx.doi.org/10.14528/snr.2015.49.3.74 